\title{
An Institutional Response to Date Rape
}

\section{DALE RAJACICH ${ }^{*}$, M. KAYE FAWDRY ${ }^{*}$, MARY L. BERRY ${ }^{*}$}

\begin{abstract}
This article reviews the existing literature on date rape and its prevention. As a result of an analysis of the literature, a model for date rape prevention on university campuses has been developed. The model is based on an adaptation of Roark's (1987) prevention strategies at the institutional level and Neuman's (1989) Total Systems Model. It provides a comprehensive approach to date rape prevention at the primary, secondary and tertiary levels of prevention. The model also includes a date rape assessment guide and sample date rape prevention program.
\end{abstract}

\section{Résumé}

Cet article examine la documentation pourtant sur "les agressions sexuelles par une connaissance" (date rape) et les mesures préventives en vigueur. Après avoir analysé la documentation pertinente, un modèle portant sur la prévention des agressions sexuelles sur les campus universitaires a été développé. Le modèle et une adaptation des stratégies institutionelles de prévention (Prevention Strategies at the Institutional Level) de Roark (1987) et du modèle des systemes (Total Systems Model) de Neuman (1989). Il vise à intégrer les stratégies de prévention de premier, deuxième et troisième niveaux. Le modèle comprend également un guide d'évaluation des agressions sexuelles et un programmme de prévention. .

\section{A Model for Institutional Response to Date Rape}

\section{Phenomenon of Date Rape}

In Canada, approximately one out of every four women has been sexually assaulted at one time in her life (Brickman \& Briere, 1984). Date rape is a particular type of violence which occurs among acquaintances and in relationships. It is a form of sexual assault which, under Canadian law, is any unwanted act of

* School of Nursing, University of Windsor 
a sexual nature (Department of Justice Canada, 1988). This form of violence permeates society as well as institutions of higher learning and is a crime, even in a dating relationship.

The seriousness of date rape has been minimized by myths about both victims and perpetrators. Consequently, date rape on campuses must be recognized as a student, institutional and community problem. There is a corresponding need to develop programs for date rape prevention, victim support, reduction of the damages of victimization and counselling of perpetrators (Roark, 1987). Therefore, the purpose of this article is twofold: (a) to review literature on date rape in order to identify trends, issues, risk factors, and preventative measures; and (b) to use Neuman's Total Systems Model (1989), along with an adaptation of Roark's (1987) prevention strategies at the institutional level, to develop a date prevention model.

Several researchers have attempted to explain the phenomenon of date rape. Korman (1983) states that, from an exchange theory perspective, it may be inferred that the more money a male spends on a date, the farther the male feels entitled to go in terms of sexual intimacy. Conversely, Yegidis (1986) suggests that the underreporting of date rape can be explained by feminist theory (Burt, 1980; Check \& Malamuth, 1983; Clark \& Lewis, 1977; Shotland \& Goodstein, 1983 ) which holds that acceptance of rape myths, sex role stereotyping, sexual conservatism acceptance of sexual violence against women, all create an atmosphere which fosters the acceptance of rape. Lewin (1985) proposes a theory of unwanted intercourse that attributes the high incidence to four societal norms: (a) current remnants of the ideology of male supremacy, (b) the norm of male initiative, (c) the lack of positive sexual experience norms for women, and (d) the "stroking norm" for women, which contends that women have been brought up to believe that they should put men's needs ahead of their own. Jenkins and Dambrot (1987) indicate that the perceptions of date rape can be viewed from the male assailant's point of view with a social-cultural perspective which postulates that rape and sexually coercive behaviour can be viewed as an extreme form of normative male behaviour supported by customs, values and attitudes (Burt, 1980; Burt \& Albin, 1981; Weis \& Borges, 1973). For women, situational factors such as (a) number of sexual partners, (b) age of first intercourse, (c) situations more appropriate to sexual intimacy such as a planned date, (d) the exchange theory of dating, or (e) the stroking functions and not attitudes - determine whether they become rape victims or will acknowledge sexual assault as rape.

Females in high school, college and university are likely candidates for date 
rape. Russell (1984) found that more women have been raped by dates and boyfriends than by strangers. Historically, between $1 / 4$ and $1 / 5$ of college women surveyed over a 20 year period have reported forceful attempts at sexual intercourse by their dates (Kanin, 1957; Kanin \& Parcel, 1977; Shotland \& Goodstein, 1983). More recently, Dull and Giacopassi (1987) report a substantial increase in the incidence of sexual assault and rape reported at colleges and universities. Yet date rape, a form of forced sexual intercourse occurring either on a date between individuals who are acquainted or romantically involved (Meyer, 1984), is the most unreported type of rape (Jenkins \& Dambrot, 1987; Russell, 1984). Research on both high school (Giarrusso, Johnson, Goodchilds, \& Zellerman, 1979) and college students (Mahoney, 1983) shows that an alarming minority believe that date rape is not rape, nor is it unacceptable behaviour under certain conditions. There is a definite reluctance to define forced sexual intercourse occurring on a date or between romantically involved couples as rape (Jenkins \& Dambrot, 1987). Furthermore, when victims know their assailants, they are less likely to label forced sexual intimacy as rape (Yegidis, 1986).

Date rape is compounded by the fact that the violence which occurs on college campuses has been largely hidden and sometimes denied. The institution may create victims by commission (policies and actions) or by omission (denial or neglect). This neglect permits abusers to remain hidden, to avoid recriminations, and to rationalize their behaviour (Hanson, Turbett, \& Whelehan, 1986).

\section{Incidence, Attributions and Factors Associated With Date Rape}

The reported incidence of date rape varies greatly. Date rape accounts for 60 percent of all rapes in society (Seligam, 1984) and may be even higher on college campuses (Yegidis, 1986). Studies have found that from 13 to 32 percent of female students are victims of date rape or attempted date rape, which may involve force (Koss, 1983; Koss \& Oros, 1982; Meyer, 1984; Wilson \& Durrenberger, 1982). A survey of 4000 male and female university students found that as many as 32 percent of the women unwillingly engaged in intercourse, thinking their partners were too aroused to stop; 20 percent felt coerced as a result of false promises; and even in cases where intercourse did not occur, 18 percent of the women had partners who threatened to use physical force (Koss \& Oros, 1982).

The attribution of date rape has been found to be a function of a number of factors. Studies using date rape scenarios have been conducted to investigate the 
attribution of rape in order to understand why date rape is so frequently unacknowledged and unreported by the female victims, and in turn justified by male assailants. Due to the complexity of the phenomenon, findings are diverse, contradictory and inconclusive.

Several studies have found a higher attribution of rape when the assailant used greater force (Burt \& Albin, 1981; Oros, Leonard \& Koss, 1980; Shotland \& Goodstein, 1983). Rape attribution also has been found to be influenced by: (a) victim characteristics, such as respectability of the victim (Riger \& Gordon, 1979; Thornton, Robbins \& Johnson, 1981), (b) physical attractiveness of the victim (DeJong, Amabile \& Stubbs, 1979), and (c) past sexual experience (Cann, Calhoun \& Selby, 1979). Burt and Albin (1981) and Malamuth (1981) also found that attribution of rape is influenced by observer characteristics and attitude. A higher rape myth acceptance reduces the possibility that a scenario will be acknowledged as a rape. Muehlenhard, Friedman, and Thomas (1985) had male undergraduates rate the justifiability of date rape under various circumstances. Subjects reported rape as significantly more justifiable: (a) if the couple went to the man's apartment rather than a religious function; (b) if the woman asked the man out; and (c) if the man paid all the expenses. Men who ranked as traditional on an attitude toward women scale rated rape as more justifiable. Fisher (1986) found that persons who were more accepting of date rape were less sure if it was really rape, had more traditional attitudes toward women, were more sexually permissive, had less accurate sexual knowledge and were slightly more inclined than others to blame society and the situation. However, Jenkins and Dambrot (1987) found some distinct differences between male and female attitudes, attributes and perception of date rape. Men, in comparison to women, had a higher acceptance of rape myths, were less likely to interpret a situation of forced sexual intercourse as rape and were more likely to perceive the victim as desiring sexual intercourse. While a man's self-reported level of previous sexually aggressive behaviour affected his rape attitude, a female's did not.

Roark (1987) identifies several factors underlying campus violence. College students are in a new setting with a variety of environmental stressors, away from direct parental supervision and old support systems, and at an age when sexual impulses are making consistent demands. They experience peer pressure, their identities are not yet firm, their competence is not yet established, they often have mistaken beliefs about their invincibility, and they live among others who are experimenting with new freedoms. Muehlenhard and Linton (1987) 
also identify several specific risk factors: (a) the man initiating the date, paying all the expenses, and driving, (b) miscommunication about sex, (c) heavy alcohol or drug use, (d) parking, and (e) men's adversarial attitudes about relationships and rape myths.

Research to date suggests that societal attitudes and myths strongly influence both males' and females' perceptions and values about date rape. These perceptions and values are culturally and morally entrenched as a result of the socialization process (Greendlinger \& Byrne, 1987; Heinrich, 1987; Larsen \& Long, 1988; Muehlenhard \& Linton, 1987; Parrot, 1985; Willmarth, 1985). Jenkins and Dambrot (1987) argue that, ultimately, prevention of date rape may depend on widespread basic societal changes in attitudes toward sex roles, aggression and sexuality and the expectations and rules of the dating game. Therefore, further research is warranted to determine the strengths of these convictions and the efficacy of date rape prevention programs.

\section{Reactions of Victims}

The literature cites a variety of reactions to date rape. The Canadian Urban Victimization Survey (1985) found that emotional distress can persist long after the actual experience, disrupting the individual's normal functioning, her trust in others, and her sense of personal security. Heinrich (1987) identifies a range of emotions, such as shock and disbelief, which may be expressed as anger, fear and anxiety. The victim may have a variety of physical reactions, such as generalized soreness or pain, as well as more specific symptoms related to the area of the body involved in the assault. These symptoms generally occur during the denial phase. Other reactions include feelings of humiliation, helplessness, rage and fear of going outside, all of which can cause long term emotional damage (Freeman, 1990).

Female students may terminate their studies as a result of: (a) polarization of students, faculty and staff regarding the incident, (b) personal humiliation, (c) encounters with the perpetrator, in class or on campus, and (d) attacks by both students and university personnel (Freeman, 1990, p. 100). Classmates and close friends also may be affected in that they may experience symptoms such as shock, disbelief, helplessness, headaches and insomnia which can impede their own learning (Heinrich, 1987).

\section{Date Rape Prevention}

The disruption of the learning environment that results from date rape is extremely serious to individuals in an academic institution. It damages both 
individuals and the institution, sometimes in irreparable ways. Individual victims may suffer in silence for a variety of reasons, including fear, embarrassment, the belief that nothing can or will be done, and self-blame for causing or contributing to the violence (Roark, 1987). Staff members, fearing possible job effects or believing that incidents are either misrepresented, distorted or hearsay, tend to overlook the violence (Hanson et al., 1986).

Several approaches to date rape prevention have been suggested in the literature, but they are fragmented, compartmentalized and directed primarily toward females (Barrett, 1982; Jenkins \& Dambrot, 1987; Shaw, 1985). Little emphasis has been placed on date rape prevention for men although it is men who rape (Jenkins \& Dambrot, 1987; Malamuth, 1981). There is a need for definitive date rape prevention programs for men and women that target either one or both sexes. These programs are slowly becoming evident in the literature (Ehrhart \& Sandler, 1985; Parrot, 1985; Willmarth, 1985). The majority of approaches, with the exception of Roark's institutional response approach, fail to address the problem of date rape from a university-wide and community perspective.

Parrot (1985) states that a number of institutions have conducted brief educational programs to raise students' awareness about the problem of date rape and to introduce prevention strategies. The basic philosophy is that women need to be prepared for and warned about the potential for date rape (Jenkins \& Dambrot, 1987). Other programs include date rape awareness, risk factors and assertiveness training. Amick and Calhoun (1987), based on Becker and Abel's (1981) rapist-victim interface, have derived four preventative intervention strategies: (a) educating women about the prevalence of acquaintance victimization; (b) enhancing women's ability to discriminate initial cues of impending victimization; (c) improving women's repertoire of resistant behaviours, with particular attention to social skills in dating situations; and (d) teaching victims to self-reinforce for assertion of their expectations and for successful prevention of undesired sexual activity (p. 162). Muehlenhard and Linton (1987) also indicate the need for crisis counselling for some students and prevention programs for both males and females. They suggest increasing awareness of date rape, assertiveness training, situational and attitudinal risk factors, familiar partners, power differential of males, miscommunication, alcohol or drug use, dating activity or location, and attitudes of both males and females. Furthermore, Yegidis (1986) and Dull and Giacopassi (1987) state that professionals working with students should be sensitive to the possibility of date rape and the reactions of victims. Yegidis (1986) stresses that if date rape occurs because of men's 
expectations for sexual intimacy, educational seminars on sexual intimacy might be conducted to provide a forum for the discussion of dating expectations.

Since the onus for date rape prevention on campus falls on the university, an organizational matrix based on Neuman's Total Systems Model (1989), along with an adaptation of Roark's (1987) prevention strategies at the institutional level, has been used to design a date rape prevention model (see Figure 1).

Neuman's model is based on the concept of stress and an individual's, group's or community's reaction to that stress. Date rape is a stressor impinging on an educational community composed of three systems: an intrasystem, intersystem and extrasystem. The intrasystem, the student population, has five variables: physiological, psychological, developmental, sociocultural and spiritual. It interacts with an intersystem, the university, consisting of eight subsystems: health and safety, sociocultural, education, communication and transportation, recreation, economics, law and politics and religion. This system, in turn, is influenced by a geopolitical extrasystem beyond the university, the community, which also is composed of the same eight subsystems. Therefore, assessment of date rape, its risk factors and prevalence, program planning and associated intervention strategies, have three levels of prevention: (a) primary prevention before a reaction to the stressor of date rape occurs, to reduce risk factors and prevent stress, (b) secondary prevention, after a reaction to the stressor of date rape occurs, to provide crisis intervention, counselling and referral, and (c) tertiary prevention, after date rape, to provide re-education and rehabilitation for males and females.

At an institutional level, Roark (1987) addresses several responses to campus violence. The author puts forth pragmatic primary, secondary and tertiary activities that can be addressed within Neuman's Total Systems Model (1989).

Roark's (1987) primary prevention targets "at-risk" groups to prevent victimization by addressing causes and changing attitudes and values relating to conditions that foster violence. The aim is to prevent dangerous situations from occurring through a date rape awareness program. Primary prevention activities include: (a) the involvement of campus police, (b) cooperative working relationships among staff members most likely to be aware of date rape (head residents, health counsellors, and student affairs personnel), (c) training of informed, sensitive, fair and caring staff members, and (d) assessment of the physical environment, including lighting, parking, telephones and escort service. Other interventions suggested are workshops for males and females to address causes, change of attitudes and the development of coping mechanisms. 


\section{FIGURE 1. A model for data rape prevention}

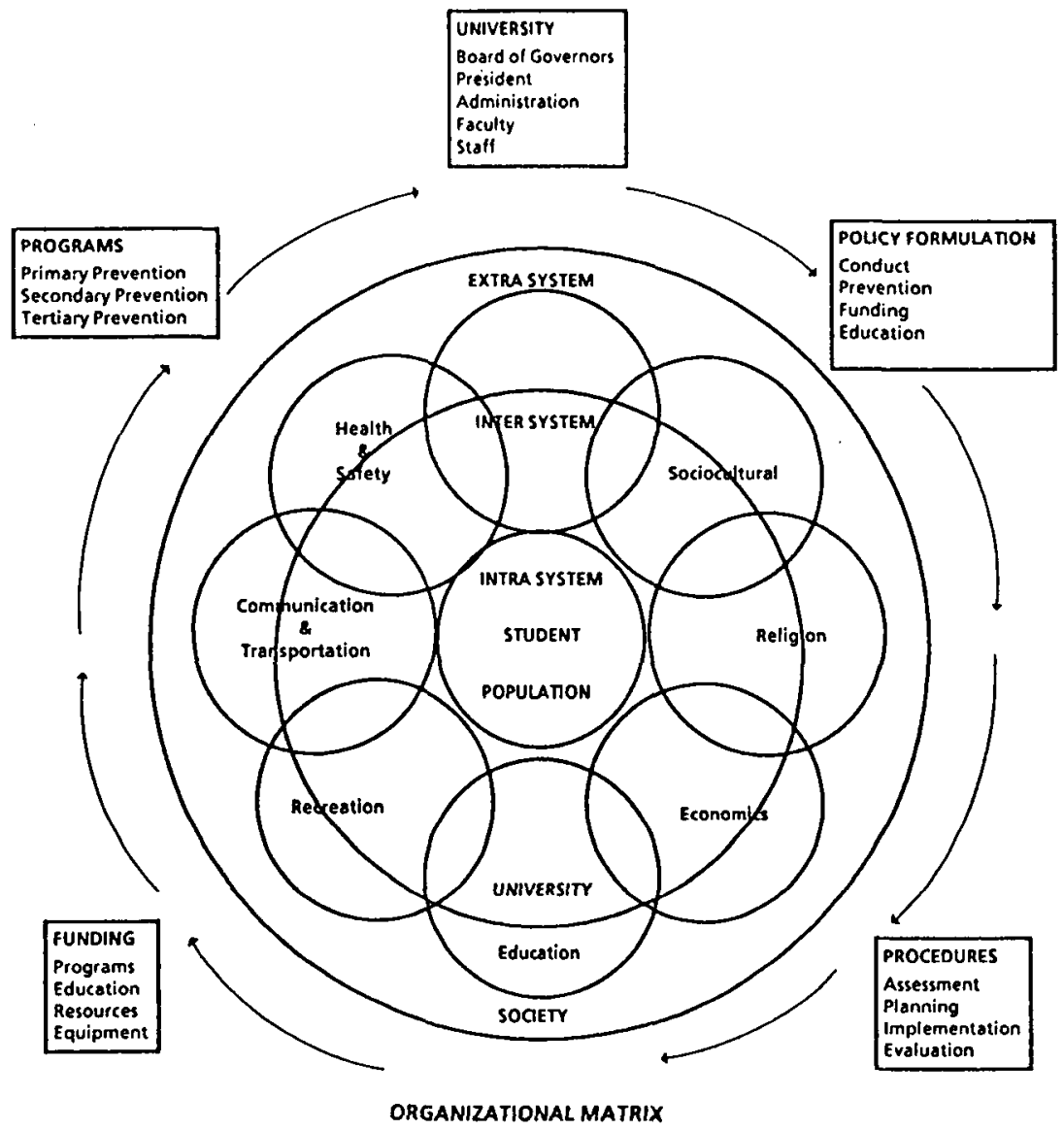


Secondary prevention is directed at date rape. It aims to identify existing problems and bring about effective corrections to minimize consequences for affected individuals. This can be accomplished best by task forces or committees which will generate clear, concise written policies and procedures to serve as powerful secondary prevention interventions. It is imperative that these policies and procedures be widely disseminated, that the campus community be educated and that new faculty, students and staff oriented be to the policies and procedures.

Tertiary prevention is like remediation and includes direct services to victims (Roark, 1987). Among these interventions are crisis management, medical care, protection, information, education regarding pursuing judicial procedures within the civil and criminal justice system, post-trauma counselling and supportive services for victims, friends, and families of victims. Perpetrators can be assisted both through judicial procedures and developmental counselling.

\section{Program Development}

An organizational matrix based on Neuman (1989) and Roark (1987) enables a university to develop a comprehensive date rape prevention program within its present organizational structure and existing staff complement (see Figure 1). The goal of such a model is to enhance both personal and academic development of male and female students and to promote a positive environment for faculty and staff.

The organizational matrix, including of the eight subsystems of the university, delineates positions, responsibilities and communication patterns required for date rape prevention. First and foremost, the Board of Governors/Regents must commit the university to a prevention program. Second, the president, senior administrative personnel and senate must set policy regarding moral/ethi.cal conduct, date rape prevention programs, education of faculty, staff and students and the allocation of existing resources. Third, senior administration must establish a university-wide committee composed of key faculty, staff and students to develop and implement primary, secondary and tertiary prevention programs. The roles, responsibilities and power of this committee must be explicit and made known to the university community through bylaws and procedures (see Table 1).

A date rape prevention assessment guide has been developed to assist a committee to assess current problems, campus resources, their utilization patterns and degree of effectiveness (see Table 2). The guide is purposefully broad in 
Table 1

Implementation of organizational matrix

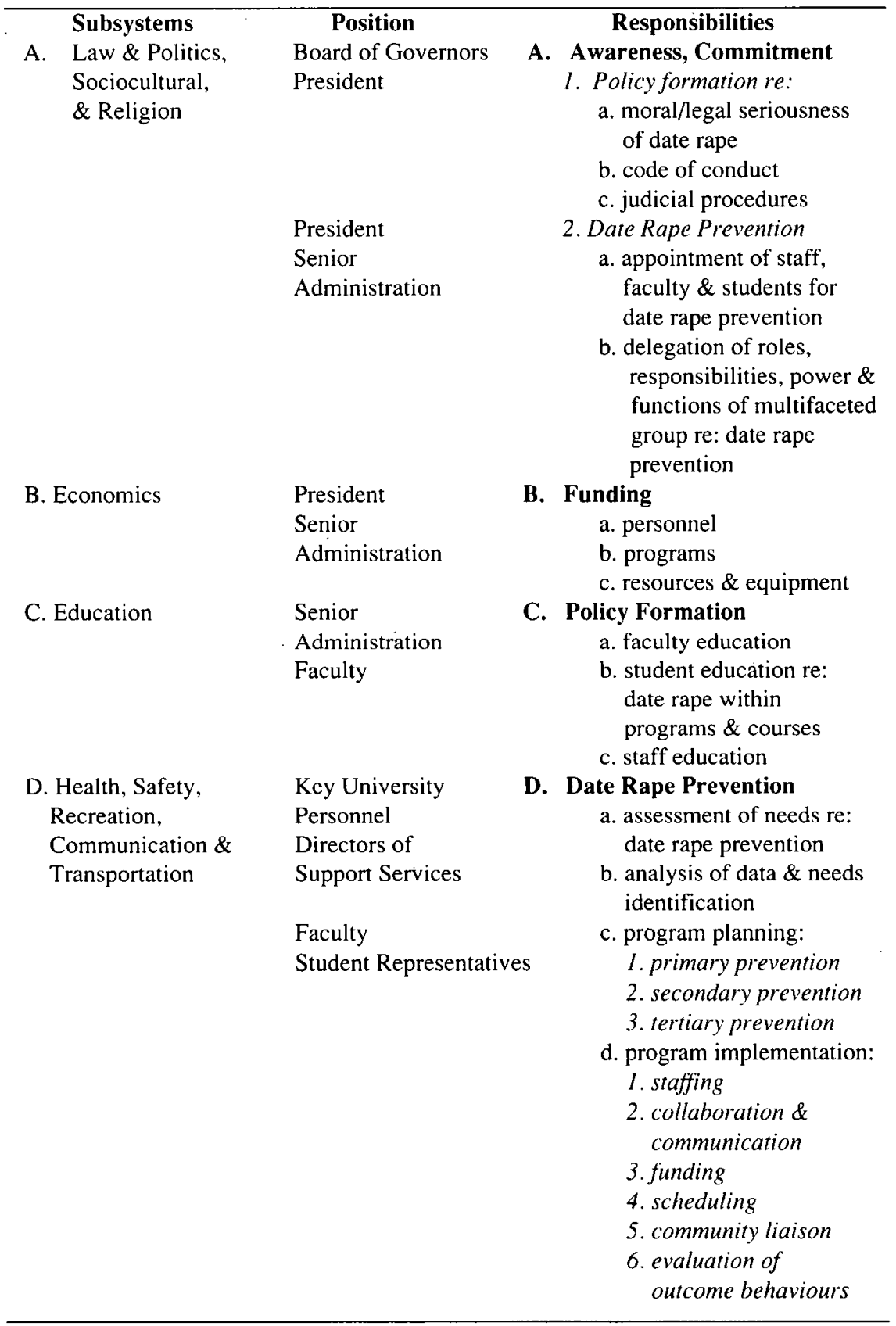


Table 2

Date rape assessment guide

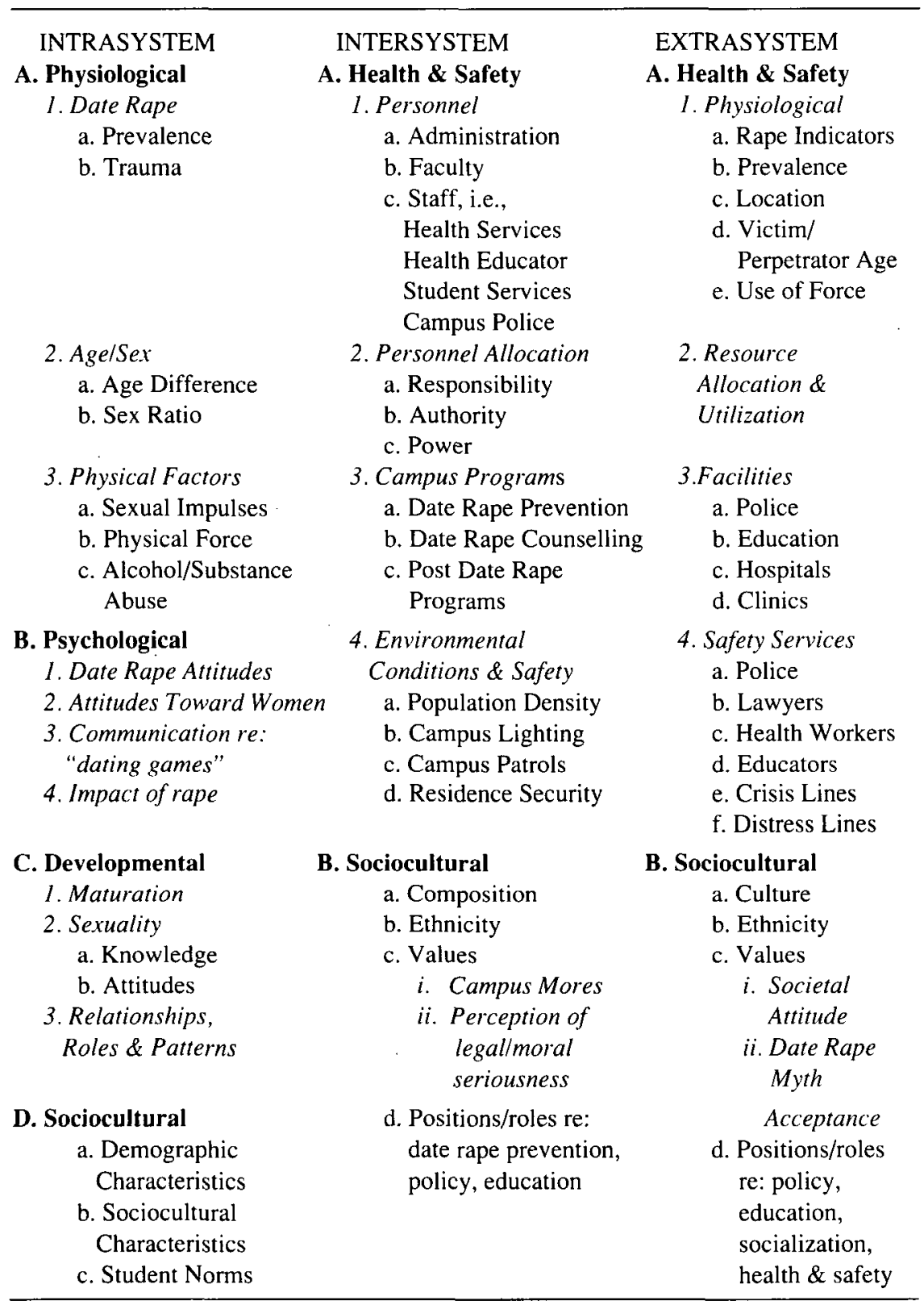


Table 2

Date rape assessment guide (cont'd)

\begin{tabular}{|c|c|c|}
\hline \multirow[t]{7}{*}{$\begin{array}{r}\text { E. Spiritual } \\
\text { a. Values } \\
\text { b. Beliefs }\end{array}$} & $\begin{array}{l}\text { C. Education } \\
\text { 1. Educational Level of } \\
\text { Personnel re: date rape } \\
\text { 2. Continuing Education } \\
\text { for Personnel }\end{array}$ & $\begin{array}{l}\text { C. Education } \\
\text { 1. Societal } \\
\text { Education } \\
\text { re: Date Rape } \\
\text { 2. Facilities } \\
\text { a. Schools } \\
\text { b. Hospitals/ } \\
\text { Clinics } \\
\text { c. Business/ } \\
\text { Industry } \\
\text { d. Government } \\
\text { e. Churches }\end{array}$ \\
\hline & $\begin{array}{l}\text { D. Communication } \\
\text { \& Transportation } \\
\text { 1. Communication } \\
\text { Patterns } \\
\text { a. re: date rape } \\
\text { prevention }\end{array}$ & $\begin{array}{l}\text { D. Communication } \\
\text { \& Transportation } \\
\text { 1. Communication } \\
\text { Patterns } \\
\text { a. re: sexual assault } \\
\text { b. judicial proce- } \\
\quad \text { dures }\end{array}$ \\
\hline & $\begin{array}{l}\text { b. re: surveillance } \\
\text { c. re: judicial } \\
\text { procedures }\end{array}$ & $\begin{array}{l}\text { 2. Liaison of key } \\
\text { social figures }\end{array}$ \\
\hline & $\begin{array}{l}\text { 2. With Agencies re: } \\
\text { date rape prevention } \\
\text { 3. With Legislative Bodies }\end{array}$ & \\
\hline & $\begin{array}{l}\text { 4. Transportation } \\
\text { a. type } \\
\text { b. access } \\
\text { c. availability }\end{array}$ & $\begin{array}{l}\text { 3. Transportation } \\
\text { a. type } \\
\text { b. cost } \\
\text { c. access } \\
\text { d. availability } \\
\text { e. safety }\end{array}$ \\
\hline & $\begin{array}{l}\text { E. Recreation } \\
\text { 1. Campus Facilities } \\
\text { a. type } \\
\text { b. location }\end{array}$ & $\begin{array}{l}\text { E. Recreation } \\
\text { I. Community } \\
\text { Facilities } \\
\text { a. type } \\
\text { b. location }\end{array}$ \\
\hline & $\begin{array}{l}\text { 2. Campus Activities } \\
\text { a. type } \\
\text { b. sponsorship }\end{array}$ & $\begin{array}{l}\text { 2. Community } \\
\text { Activities } \\
\text { a. type } \\
\text { b. sponsorship }\end{array}$ \\
\hline
\end{tabular}




\section{Table 2}

Date rape assessment guide (cont'd)

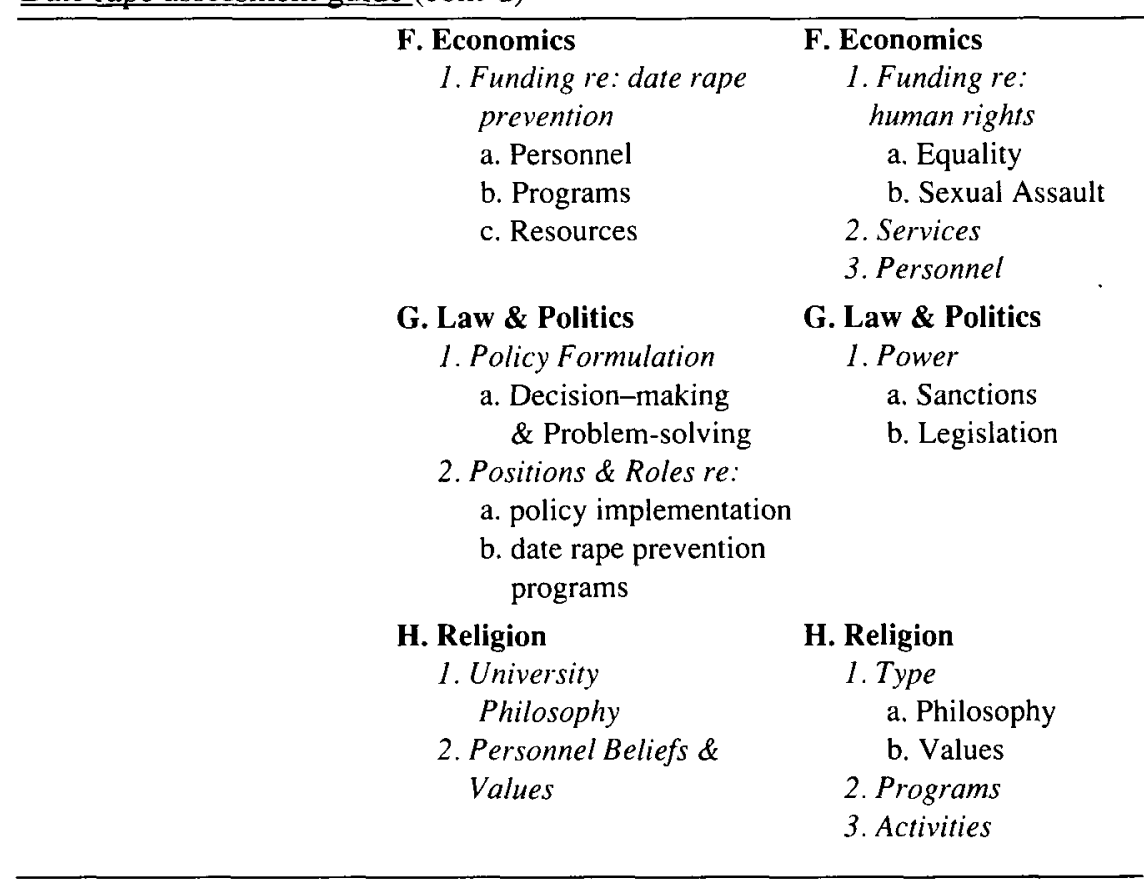

scope, to allow for the collection and analysis of general or more specific information, as deemed necessary by the institution.

Several methods of data collection can be utilized. For example, assessment data may be collected through the use of key informant interviews of faculty, students, staff, community crisis centres, health care personnel and police departments to determine: a) the severity of the problem; b) perceptions of date rape, and associated myths; and c) the magnitude of the problem. Questionnaires such as: (a) Sexual Assertiveness Questionnaire (Parrot, 1985), (b) Acquaintance Rape Awareness Values Clarification Continuum Rating (Parrot, 1985) and (c) Date Rape Awareness Questionnaire for men (Willmarth, 1985) also can be utilized.

Assessment of the intrasystem, the students, is needed to identify the physiological, psychological, developmental, sociocultural and spiritual variables of the population with its varying degrees of development and wide variety of interactive styles and potential. Assessment of the eight subsystems of the 
intersystem, the university, is required to determine their positive or negative influence on the student population as well as to identify existing problems at the university-wide level. While the extrasystem or social system is beyond the bounds of the campus, the collection and analysis of these data are required to 'determine this system's influence on both the student population and the university. Analysis of data by a committee can lead to accurate diagnoses and will enable the committee to generate both programs and a structure for their implementation (see Table 2.)

Programs at the three levels of prevention must be directed at problems identified in assessment (see Table 3). It is essential at this stage that administrative support be evident through clear, concise policies and procedures regarding student conduct, the seriousness of date rape, the fact that use or abuse of alcohol is not an excuse for date rape and that, if date rape occurs, it will be handled not by the university, but through the civil or criminal judicial system.

Emphasis should first be placed on primary prevention programs. The goal is date rape prevention and reducing risk factors that make both male and female students vulnerable. For example, date rape awareness programs for males and females should be a mandatory part of student orientation for new students and reinforced in every class on campus.

An educational program co-sponsored by the student administrative council, health education, student services and campus police should be conducted throughout the academic year. This program should address, through student forums, the date rape myths, dating expectations, relationship enhancement, and values development. Special programs for women should be conducted by health educators and peer counsellors on risk factor awareness and assertiveness training. Student administrative services and peer counsellors should be responsible for programs for males on date rape. These programs should complement other programs, with sessions about alcohol and substance use and stress management. Support groups for both males and females should be set up in residences, along with a peer counselling network including both male and female students.

Continuing education programs for faculty should be conducted through faculty groups and associations, and for staff through Employee Assistance Programs. In addition, the high visibility of campus police is needed to ensure safety and to monitor campus events.

Secondary prevention programs are required to assist females who are victims of date rape, as well as their perpetrators. A procedure must be in place to 


\section{Table 3}

Sample student date rape prevention program

\begin{tabular}{|c|c|c|}
\hline $\begin{array}{l}\text { Primary } \\
\text { Prevention }\end{array}$ & $\begin{array}{l}\text { Secondary } \\
\text { Prevention }\end{array}$ & $\begin{array}{c}\text { Tertiary } \\
\text { Prevention }\end{array}$ \\
\hline $\begin{array}{c}\text { * Date Rape Awareness } \\
\text { Orientation Programs }\end{array}$ & * Medical Care Referral & $\begin{array}{l}\text { * Rehabilitation } \\
\text { a. Post Trauma } \\
\text { Referral } \\
\text { Program }\end{array}$ \\
\hline $\begin{array}{l}\text { * University Sanctioned } \\
\text { brochure on Student } \\
\text { Conduct/Date Rape } \\
\text { Awareness }\end{array}$ & * Crisis Counselling & $\begin{array}{l}\text { b. Peer } \\
\text { Counselling }\end{array}$ \\
\hline $\begin{array}{l}\text { * Student Forum/Programs } \\
\text { a. Date Rape Myths } \\
\text { b. Dating Expectations } \\
\text { c. Relationship } \\
\text { Enhancement } \\
\text { d. Values Development }\end{array}$ & $\begin{array}{l}\text { * Community Agency } \\
\text { Referral } \\
\text { * Peer Support Program }\end{array}$ & $\begin{array}{l}\text { * Victim/Perpetrator } \\
\text { Re-education } \\
\text { Programs } \\
\text { a. Self-Help } \\
\text { Groups } \\
\text { b. Developmental } \\
\text { Counselling } \\
\text { c. Relationship }\end{array}$ \\
\hline $\begin{array}{l}\text { * Risk Factors Awareness, } \\
\text { Assertiveness Training } \\
\text { for Women }\end{array}$ & $\begin{array}{l}\text { * Judicial Procedures } \\
\text { Information }\end{array}$ & $\begin{array}{l}\text { d. Values } \\
\text { Clarification } \\
\text { e. Anger } \\
\text { Management }\end{array}$ \\
\hline $\begin{array}{l}\text { * Responsible Alcohol } \\
\text { Use Program }\end{array}$ & & \\
\hline $\begin{array}{l}* \text { Substance Abuse } \\
\text { * Stress Management } \\
\text { Program }\end{array}$ & & \\
\hline $\begin{array}{l}\text { * Student Services Support } \\
\text { Peer Counselling } \\
\text { Support Groups }\end{array}$ & & \\
\hline
\end{tabular}


provide direct services or make referrals to community agencies. Programs must be in place whereby females can seek immediate physical and psychological assistance counselling and referral, if necessary, through a sexual assault advisory or peer support student program. Victims must be informed of their rights and judicial avenues open to them by sensitive campus police or sexual assault advisors. Campus police should inform alleged perpetrators of their rights and of the available support services. Peer support groups can assist with psychological support and referral to crisis counselling and alcohol and/or substance abuse programs.

Tertiary prevention should focus on rehabilitation and re-education of victims and perpetrators through post-trauma counselling of both males, females and friends. Developmental counselling, relationship enhancement, values clarification and anger management programs can be conducted by health educators, peer counsellors and self-help groups. Referrals can be made to community agencies for further rehabilitation.

This sample date rape prevention program is an example of the possible measures that a university can take to prevent date rape, and to support and rehabilitate individuals after date rape.

\section{Conclusion}

As Roark (1987) points out, the prevention of date rape depends not so much on uncovering unique and fresh approaches for addressing a problem, as it does on commitment to the use of already known approaches for addressing a problem that is clearly unacceptable to most persons. This article has provided research on date rape, possible explanatory theories, and a model for an institutional response to date rape. Such a comprehensive model may be difficult to implement in its entirety immediately. Universities, however, can no longer ignore date rape on campuses. They must begin, at once, to work toward the prevention of date rape, on as large a scale as possible, with the full commitment of administration, faculty, staff and students.

\section{References}

Amick, A.E., \& Calhoun, K.S. (1987). Resistance to sexual aggression: Personality, attitudinal, and situational factors. Archives of Sexual Behaviour, 16, 153-163.

Barrett, K.C. (1982, September). Date rape: A campus epidemic? Ms. Magazine, 217-220.

Becker, J.V., \& Abel, G.G. (1981). Behavioral treatment of victims of sexual assault. In S.M. Turner, K.S. Calhoun, \& H.E. Adams (eds.), Handbook of clinical behavior therapy. New York: Wiley-Interscience, 347-379. 
Brickman, J., \& Briere, J. (1984). Incidence of rape and sexual assault in an urban Canadian population. International Journal of Women's Studies, 7 (3), 195-206.

Burt, M.R. (1980). Cultural myths and supports for rape. Journal of Personality and Social Psychology, 38, 217-230.

Burt, M.R., \& Albin, R.S. (1981). Rape myths, rape definitions and probability of conviction. Journal of Applied Social Psychology, II, 212-238.

Cann, A., Calhoun, L.G., \& Selby, J.W. (1979). Attributing responsibility to the victim of rape: Influence of information regarding past sexual experience. Human Relations, $32,57-67$.

Check, J.V.P., \& Malamuth, N.M. (1983). Sex role stereotyping and reactions to depictions of stranger versus acquaintance rape. Journal of Personality and Social Psychology, 45, 344-356.

Clark, L., \& Lewis, D. (1977). Race: The price of coercive sexuality. Toronto: Women's Press.

DeJong, W., Amabile, T.N., \& Stubbs, M.L. (1979, September). Rape and physical attractiveness: Judgements concerning the likelihood of victimization. Paper presented at the meeting of the American Psychological Association, New York, N.Y.

Department of Justice Canada. (1988). After sexual assault: Your guide to the criminal justice system (Cat. No. J2-62). Ottawa: Minister of Justice and Attorney General of Canada.

Dull, R.T. \& Giacopassi, D.J. (1987). Demographic correlates of sexual and dating attitudes: A study of date rape. Criminal Justice and Behaviour, 14, 175-193.

Ehrhart, J.K., \& Sandler, B.R. (1985). Campus gang rape: Party games? Washington: Project on the Status and Education of Women.

Fisher, G.J. (1986). College students' attitudes toward forcible date rape: Cognitive predictors. Archives of Sexual Behaviour, 15, 457-466.

Freeman, P. (1990, December). Silent no more. People Weekly, pp. 94-104.

Giarrusso, R., Johnson, P., Goodchilds, J., \& Zellerman, C. (1979, April). Adolescents' cues and signals: Sex and assault. In P. Johnson (Chair), Acquaintance rape and adolescent sexuality. Symposium conducted at the meeting of the Western Psychological Association, San Diego.

Greendlinger, V., \& Byrne, D. (1987). Coercive sexual fantasies of college men as predictors of self-reported likelihood to rape and overt sexual aggression. The Journal of Sex Research, 23, 1-11.

Hanson, D., Turbett, J.P., \& Whelehan, P. (1986). Interpersonal violence: Addressing the problem on a college campus. In J.W. Kalas \& K. Lott (eds.), Proceedings of the University Symposium on Personal Safety (pp. 7-25). Albany: State University of New York.

Heinrich, L.B. (1987). Care of the female rape victim. Nurse Practitioner, 12 (11), 9-27.

Jenkins, N.J., \& Dambrot, F.H. (1987). The attribution of date rape: Observers' attitudes and sexual experiences and the dating situation. Journal of Applied Social Psychology, 17, 875-895. 
Kanin, E.J. (1984). Date rape: Unofficial criminals and victims. Victimology: An International Journal, 9, 95-108.

Kanin, E. (1957). Male aggression in dating-courtship relations. American Journal of Sociology, 63, 197-204.

Kanin, E.J., \& Parcell, S.R. (1977). Sexual aggression: A second look at the offended female. Archives of Sexual Behaviour, 6, 67-71.

Korman, S.K. (1983). Non-traditional dating behaviour: Date initiation and date expense sharing among feminists and nonfeminists. Family Relations and Journal of Applied Family and Child Studies, 32, 575-581.

Koss, M.P. (1983, Summer). The scope of rape: Implications for the clinical treatment of victims. The Clinical Psychologist, pp. 88-91.

Koss, M.P., \& Oros, C.J. (1982). Sexual experiences survey: A research instrument investigating sexual aggression and victimization. Journal of Consulting and Clinical Psychology, 50, 455-457.

Larsen, K.S., \& Long, E. (1988). Attitudes toward rape. The Journal of Sex Research, 24, 299-304.

Lewin, M. (1985). Unwanted intercourse: The difficulty of saying no. Psychology of Women Quarterly, 9, 184-192.

Mahoney, E.R. (1983), Human sexuality. New York: McGraw-Hill.

Malamuth, N.M. (1981). Rape proclivity among males. Journal of Social Issues, 37 (4), $138-157$.

Malamuth, N.M., \& Check, J.V.P. (1983). Sexual arousal to rape depictions: Individual differences. Journal of Abnormal Psychology, 92, 55-67.

Meyer, T.J. (1984). Date rape: A serious campus problem that few talk about. Chronicle of Higher Education, 29(15), 1-12.

Muehlenhard, C.L., \& Linton, M.A. (1987). Date rape and sexual aggression in dating situations: Incidence and risk factors. Journal of Counselling Psychology, 34, $186-196$.

Muehlenhard, C.L., Friedman, D.E., \& Thomas, C.M. (1985). Is date rape justifiable? The effects of dating activity, who initiated, who paid and men's attitudes toward women. Psychology of Women Quarterly, 9, 297-310.

Neuman, B.C. (1989). The Neuman Systems Model (2nd ed.). Norwalk: Appleton \& Lange.

Oros, C.J., Leonard, K., \& Koss, M.P. (1980, September). Factors related to a self attribution of rape by victims. Paper presented at the American Psychological Association Meeting, Montreal, Canada.

Parrot, A. (1985). Acquaintance rape and sexual assault prevention training manual. Ithaca: Cornell University.

Riger, S., \& Gordon, M.T. (1979). The structure of rape prevention beliefs. Personality and Social Psychology Bulletins, 5, 186-190. 
Roark, M.L. (1987). Preventing violence on college campuses.Journal of Counselling and Development, 65, 367-370.

Russell, D. (1984). Sexual exploitation: Rape, child sexual abuse and sexual harassment. Beverly Hills: Sage.

Seligam, J. (1984, April). The date who rapes. Newsweek.

Shaw, J. (1985, November). Date rape: Dirty little social secret. Woman's Day, pp. 89-90, 136-137.

Shotland, R., \& Goodstein, L. (1983). Just because she doesn't want to doesn't mean it's rape: An experimentally-based causal model of the perception of rape in a dating situation. Social Psychology Quarterly, 46 (3), 220-232.

Solicitor General Canada. (1985). Female victims of crime. Canadian Urban Victimization Survey Bulletin (Cat. No. JS42. 18/4). Ottawa: Programs Branch, Ministry of the Solicitor General.

Thornton, B., Robbins, M.A., \& Johnson, J.A. (1981). Social perception of the rape victim's culpability: The influence of respondent's personal-environmental causal attribution tendencies. Human Relations, 34, 225-237.

Weis, K., \& Borges, S.S. (1973). Victimology and rape: The case of the legitimate victim. Issues in Criminology, 8, 71-115.

Willmarth, M. (1985, March). A rape awareness program for men. Paper presented at the national convention of the A.C.P.A, Boston.

Wilson, W., \& Durrenberger, R. (1982). Comparison of rape and attempted rape victims. Psychological Reports, 50, 198.

Yegidis, B.L. (1986). Date rape and other forced sexual encounters among college students. Journal of Sex Education and Therapy, 12 (2), 51-54.1 